\title{
Financial Risk Analysis and Prevention of Chinese Real Estate Enterprises
}

\author{
Yi Liu ${ }^{\mathrm{a}}$, Siran Wang ${ }^{\mathrm{b}}$ and Meiyan YANG ${ }^{\mathrm{c}}$ \\ Business School, University of Jinan, P.R.China \\ a921089327@qq.com, b731208868@qq.com, '634500456@qq.com
}

Keywords: Real Estate Business, Financial Risk, Internal Control

\begin{abstract}
China's real estate industry has risen too much in prices, bringing a series of social and economic issues, this paper analyses the financial risk factors of the real estate and finds that real estate enterprises should take effective financial risk prevention measures to find suitable financial risk prevention and the method of control for China's real estate business according to the different situations, in order to establish a more scientific and reasonable financial risk control system.
\end{abstract}

\section{Introduction}

In the 1980s, China 's real estate is in its infancy stage, after more than 30 years, its own strength is further strengthened. The real estate industry plays an irreplaceable role in the investment and consumption. The global economic crisis broke out in 2008, the whole international economic environment had appeared a comprehensive recession, the real estate business developed more slowly, even had a certain degree of shrinking, the State Council put forward the object that investing 4 trillion to rescue the country in two years, to restore confidence of the public for the real estate industry, to expand investment in the real estate and increase housing prices.The Chinese government had introduced a series of economic policies such as raising interest rates,restricting house purchases and raising loan interest rates to control the "overheating" phenomenon in the development of the real estate industry.[1]Most real estate enterprises have financial risk of different levels, they should observe and identify the risks in time and develop an effective strategy to improve the level of risk prevention.

\section{Literature Review}

Philipp Hartmann's paper entitled "Real Estate Markets and Macroprudential Policy in Europe" was published in Journal of Money, Credit and Banking (2015), it pointed out that the correct guidance of national economic policies is the important condition of healthy development of the European real estate industry. Stating financial risk of the external environment factors in the real estate from the macro point of view, he hoped that the government should give the real estate industry more clear and effective means to promote the prosperity of the industry as a whole. The paper "Where will China's real estate market go under the economy's new normal?" of Hong Zhang, Linjun Li, Tiantian Chen, Vera $\operatorname{Li}(2016)$ pointed out that under the new economic situation, how to develop China's real estate industry, this paper thought China's current economic structure tended to be reasonable, the mode of economic development was transformed into the development of investment and innovation. In the relatively early period of China, Guoqun Yan's paper introduced the classification of financial risks in the real estate enterprises, including financial budget risk, cash flow management risk, the risk of operation, the risk of capital structure and the risk of internal control, the paper entitled "The Causes and Control Measures of Financial Risks of Real Estate Enterprises" published in "Northern Economy and Trade" (2012).At the same time, according to the characteristics of each classification, it put forward the corresponding measures, and pointed out that the financial risk has the characteristics of long investment period, huge investment and high yield. Xu He described the basic connotation and specific performance of financial risk in the real estate business in his paper published in 2015, and he indicated that the real estate business need to take effective control strategy: enhancing the awareness of financial risk control, raising awareness 
of the chain of risk control, responding to the market flexibly and constructing a scientific risk management early warning mechanism.

\section{Analysis on the Effect Factor of Financial Risk in Real Estate Enterprise}

Analysis on External Factor of the Financial Risk in Real Estate Enterprises. First, the real estate industry, China's macroeconomic and all things have the same process of the development, they show a certain regularity. When the government tighten monetary policy, it will greatly combat the confidence of the real estate business in the market investment. If the real estate income is less at this time, it can cause enterprises to enter the stage of sluggish, it also causes a serious decline in prices to threat the financial security of enterprises.

Second, market risk is made up of price, purchasing power and reinvestment risk. In recent years, the number of real estate enterprises is growing, the market competitive pressure is increasing, unstable income will make the financial risk larger.[3]Too high price that is far beyond the scope which public can bear and it will begin to threat the country's long-term stability, the government introduces a series of policies and regulations to regulate the real estate market, leading to market risk.

Analysis on Internal Factors of the Financial Risk in Real Estate Enterprises. First, most companies are still meeting the demand for funds through bank loans, bank lending rates remain high, the costs of the real estate companies are increasing, thereby it causes a high financial risk.

Second, the risk awareness of business managers is weak. Financial risk always presents in the whole financial managing activities, and it is the problem that enterprise management and financial personnel must pay attention to. However, due to the lack of mature management experience in China in this industry, coupled with a lot of management and financial staff's short of awareness for the objective existence of the financial risk, there are some drawbacks in risk prevention, so they are at a disadvantage in the market competition.

Third, the capital structure of the enterprise is unreasonable. Most of the firms have less funds but have huge amounts of debt, and higher debt-to-capital ratios lead to higher corporate asset-liability ratios, which will generate more financial risks.

At last, the internal business situation and the level of financial management are poor. The level of the internal business situation and financial management will be directly related to the financial risks of the enterprise. If level of internal management of enterprise is low, then information systems will be relatively closed, it has responded slowly and controlled weakly when there is some kinds of management and financial problems, and it will be a great threat to financial security.

\section{Analysis and Evaluation of Financial Risk of Real Estate Enterprises}

The HD Group is a leader in the Chinese real estate industry, and is also has advantage in high quality of real estate. However, the enterprise with good social image will also face financial risks. This paper will analyze the company's cash flow capacity, solvency capacity, development capacity, profitability capacity and other aspects.

Analysis of Solvency Capacity Indicators.

Table 1 Analysis of flow ratio index

\begin{tabular}{ccccc}
\hline Project/Years & 2012 & 2013 & 2014 & 2015 \\
\hline Flow ratio & 1.33 & 1.54 & 1.43 & 1.34 \\
Quick ratio & 0.35 & 0.56 & 0.51 & 1.34 \\
\hline
\end{tabular}

In the past four years, the flow ratio of the HD group was under 2,below the market average. The decline in the proportion of enterprises in 2015 showed that the solvency of enterprises was weakened, the short-term asset flows and financial risks were relatively large. 
Table 2 Asset - liability ratio

\begin{tabular}{ccccc}
\hline Project/Year & 2012 & 2013 & 2014 & 2015 \\
\hline Asset-liability [\%] & 82.56 & 77.21 & 76.31 & 81.22 \\
\hline
\end{tabular}

$70 \%$ of the asset-liability ratio is the cordon of the real estate business, but the asset-liability of HD Group had been too high and more than a cordon about four years, although companies could expand the scale of borrowing to use financial leverage to obtain more benefits, at the same, while it increased the risk of long-term solvency.

Analysis of Enterprise Profitability.

Table 3 Profitability index

\begin{tabular}{ccccc}
\hline Profitability index /Year & 2012 & 2013 & 2014 & 2015 \\
\hline Operating margin[\%] & 25.32 & 26.74 & 25.63 & 24.27 \\
Operating net profit margin [\%] & 14.07 & 14.64 & 16.17 & 13.02 \\
Return on equity [\%] & 26.15 & 31.57 & 36.14 & 33.96 \\
Total return on assets [\%] & 3.84 & 3.62 & 2.66 & 2.82 \\
\hline
\end{tabular}

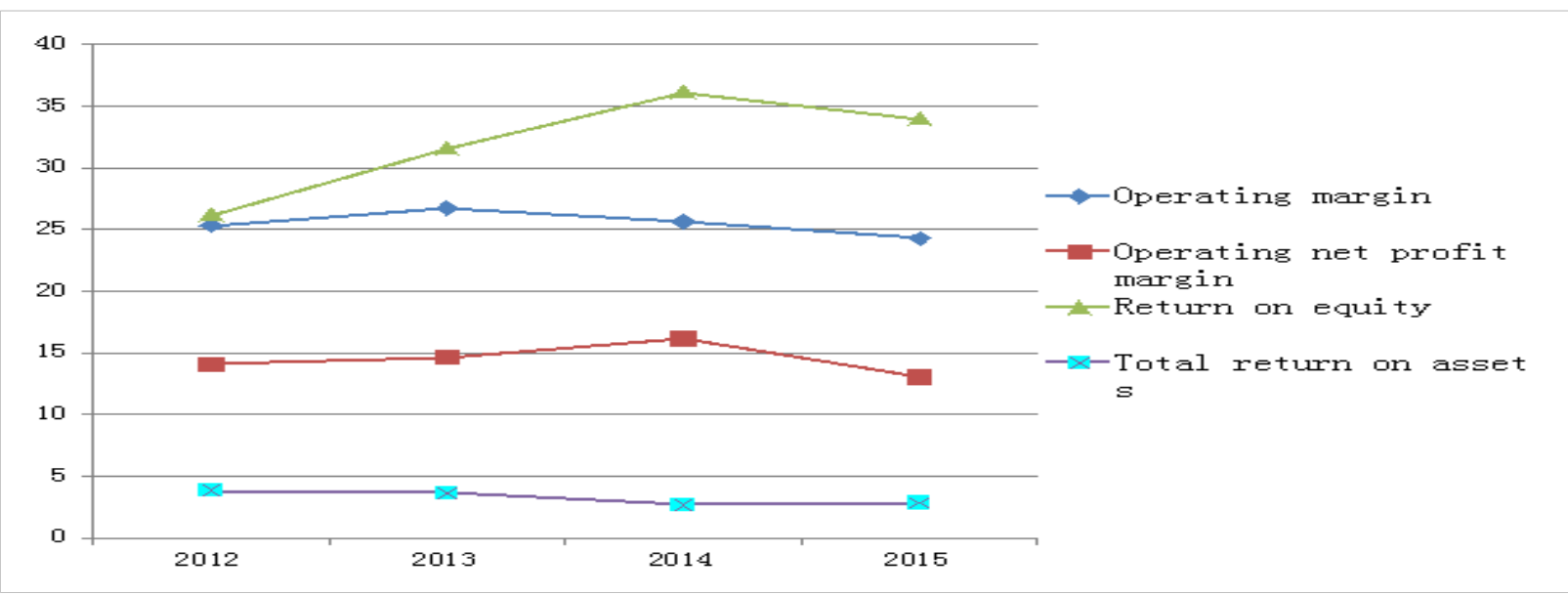

Fig. 1 Profitability indicator

It can be seen from the figure that the HD Group's profit margin declined slightly in 2015, and it was still at a relatively high level and could maintain a steady growth. The return on net assets showed a relatively stable growth rate, the yield was also much higher than the bank's long-term lending rates, indicating that enterprises got high return on investment, profitability was more robust. The return on total assets showed a downward trend year by year, which was related to large-scale debt investment in three or four lines to increase sales. It indicated that the introduction of national economic policies, domestic and international economic environment had caused some hindrance to the profit of real estate in recent years, it also increased financial risk.

\section{Analysis on the Operational Capability of Enterprise 's Assets.}

Table 4 Enterprise assets operating capacity index

\begin{tabular}{ccccc}
\hline Project/Years & 2012 & 2013 & 2014 & 2015 \\
\hline Total asset turnover & 0.27 & 0.32 & 0.31 & 0.22 \\
Current asset turnover & 0.33 & 0.38 & 0.38 & 0.27 \\
Inventory turnover & 0.37 & 0.40 & 0.38 & 0.77 \\
\hline
\end{tabular}

The figure shows that the turnover rate of corporate assets is rising from 2012 to 2014, it declines a little in 2015,but the effect is generally high. The company's inventory turnover rate has increased 
in the past four years, and the degree is higher in 2015, the reason is that the enterprise continue to obtain resources projects and product, resulting in inventory's growing and overall size's expanding, therefore the enterprises obtain more real estate resources.

Conclusions. The real estate enterprise should not only focus on project evaluation and investment analysis in its daily operations and develop a reasonable financial objective according to the real financial situation, but also optimize the warning mechanism, and fully utilize the role of supervision, control, management. Establishing a good financial structure and using financial leverage to ensure the safety of capital operation; saving costs to enhance business efficiency, thereby reducing financial risk.

\section{Financial Risk Control Strategy of Real Estate Enterprises}

Debt Risk Control. Too high debt ratio has been a serious trouble of the real estate business, if the enterprises pay no attention to the debt ratio, and have no tight control of financial management means, the financial risk of enterprises will increased and even go bankrupt. Enterprises must have a relatively accurate judgment on their own development scale, the pace of development and future development plan, and determine a reasonable proportion of debt on the basis of this judgment.[4]

Profit Risk Control. The real estate business has long cycle and large investment, so the housing price is high. Consumers will have a long time to consider the comparison carefully before the purchase, which requires companies to do a good job of pre-publicity work. Companies should set up sales strategy, grasp the entire market accurately, open up different types of consumption areas to combine with their own development capacities.

Operational Risk Control. The funds of real estate business is huge, but its liquidity is not strong, for its operating characteristics, they must use a higher turnover rate of current assets to improve the safety of corporate funds. In the process of project development, in order to ensure flexible cash flow, it is necessary form a reasonable ratio of internal types of assets.

\section{Acknowledgements}

This paper obtained the funding of the National Social Science Fund Project Environmental Audit of Ecological Civilization Construction (project approval No: 15AGL015); Transformation and Upgrading of China's Manufacturing Industry Coupled with Rising Labor Costs Research (project approval No: 16BGL098); Shandong Province Social Science Planning Project Evaluation and Countermeasures on Ecological Civilization in Shandong Province Construction Performance (project approval No: 15BKJJ04) .

\section{References}

[1] M.Z. Li and M. Song. Research on the Current Situation and Control of Financial Risk in Enterprises[J]. China Management Informationization, 2015,(5):40-41.(In Chinese)

[2] X. He. The Formation Mechanism and Control Strategy of Financial Risk of Real Estate Enterprises[J]. Contemporary economy, 2015,(20):64-65.(In Chinese)

[3] Z. Wang. Research on Financial Risk Control of Real Estate Enterprises[J]. Accounting study, 2015,(12):71-72.(In Chinese)

[4] T. Wang. Prevention and Control of Financial Risk of Real Estate Enterprises[J]. Finance and Economics (Academic Edition), 2013,(14):194.(In Chinese) 